Режим доступу: http://www.uz.gov.ua «Деякі питання функціонування /press_center/up_to_date_topic/408332/

8. Постанова Кабінету Міністрів державного підприємства "Донецька України від 29 грудня 2014p. №1284-р залізниця" [Електронний ресурс]. - Режим доступу : http:// www.zakon1.rada.gov.ua.

Стаття надійшла: 15.09.16p.

УДК 614.883 (045)

\title{
СТВОРЕННЯ ДІЄВОЇ СИСТЕМИ БЕЗПЕКИ ТУРИЗМУ, ЯК ОДНА ІЗ ОСНОВНИХ УМОВ ПІДВИЩЕННЯ КОНКУРЕНТОСПРОМОЖНОСТІ ТУРИСТИЧНОЇ ГАЛУЗІ УКРАЇНИ
}

\author{
Чередниченко О.Ю., к.е.н., доцент, \\ Чередниченко А.О., к.е.н., асистент (ХНУМГ імені О.М. Бекетова)
}

У статті розглянуті питання необхідності запровадження роботи, спрямованоі на розбудову системи безпеки туристичної галузі, запропоновані иляхи реалізаиії иієї задачі, в тому числі з використанням іноземного досвіду. Автором пропонується класифікація туристичної безпеки за змістом. Здійснена спроба розробки теоретикометодологічних основ дослідження безпеки туризму як основної умови підвищення конкурентоспроможності туристичної галузі Украӥни.

Ключові слова: туризм, безпека, небезпека, ризики у туризмі, система безпеки, конкурентоспроможність

\section{СОЗДАНИЕ ДЕЙСТВЕННОЙ СИСТЕМЫ БЕЗОПАСНОСТИ ТУРИЗМА, КАК ОДНО ИЗ ОСНОВНЫХ УСЛОВИЙ ПОВЫШЕНИЯ КОНКУРЕНТОСПОСОБНОСТИ ТУРИСТИЧЕСКОЙ ОТРАСЛИ УКРАИНЫ}

\author{
Чередниченко А.Ю., к.е.н., доцент, \\ Чередниченко А.А., к.е.н., ассистент (ХНУГХ А.Н. Бекетова)
}

В статье рассматриваются вопросы необходимости организации работы, направленной на создание ситемь безопасности туристической отрасли, предложень пути реализации этой задачи, в том числе с использованием иностранного опыта. Автором предлагается классификация туристической безопасности. Предпринята попылтка разработки теоретико-методологических основ исследования безопасности туризма как основного условия повышения конкурентоспособности туристической отрасли в Украине.

Ключевые слова: туризм, безопасность, опасность, риски в туризме, система безопасности, конкурентоспособность.

() Чередниченко О.Ю.,

Чередниченко А.О.
Вісник економіки транспорту і промисловості № 55, 2016 


\title{
CREATION OF THE EFFICIENT SYSTEM OF TOURISM SECURITY AS ONE OF THE MAIN CONDITIONS FOR IMPROVEMENT OF THE COMPETITIVENESS OF THE TORUISM INDUSTRY OF UKRAINE
}

\author{
Cherednychenko O.Yu., Ph.D. in Economics, Docent \\ Cherednychenko A.O., Ph.D. in Economics, assistant \\ (O.M. Beketov National University of Urban Economy)
}

The article analyses the scholarly approaches to the determination of issue "the tourism security" and concludes that the tourism security has the system-forming nature in the tourism activity, is a key component of the consumer peculiarity of the tourism services. The article considers the issues of the necessity of introduction the work aimed at the development of the tourist industry security system. The author suggests the classification of the tourist security according to the content. The attempt was made to develop the theoretical and methodological grounds of the tourism security research as a key condition of improvement the tourist industry of Ukraine. The methods were suggested of the tourism security realization, including with the implementation of the foreign experience. It was determined that the steps on improvement the security in the tourism in our country have to be implemented in the following two directions: first of all, insurance of the complex security issues, secondly, insurance of the direct security of tourists. Coordinated common work in the tourism security organization on the following levels: state - regional regulatory and administrative authorities- tourism sector (tour operators and tour agencies) - tourist, will facilitate the arrangement of security measures on the systemic, efficient level.

Key words: tourism, security, danger, risks in tourism, security system, competitiveness

Постановка проблеми та ї̈ зв'язки з науковими чи практичними завданнями. Закон України «Про туризм» визначає туризм як тимчасовий виїзд особи 3 місця постійного проживання в оздоровчих, пізнавальних, професійноділових чи інших цілях без здійснення оплачуваної діяльності в місці перебування[1].

Туризм - це галузь світового масштабу 3 щорічним обігом понад трильйон доларів США, що впливає не тільки на економіку, а і на устрій багатьох держав i регіонів. Україна не $\epsilon$ виключенням, перш за все як країна із значним туристичним потенціалом, який здатний позитивно вплинути на процес оздоровлення національної економіки. Розвитку туризму сприяють різні фактори. До них можна віднести конкуренцію, інформаційні технології, перевезення, туроператорські послуги, політичні i соціальні обставини в країні. У системі туризму тісно, окрім економічних питань, міжнародних відносин, зайнятості населення, транспортних організацій, пов'язані питання безпеки. Сьогоднішня соціально-економічна та політична ситуація в світі має багато негараздів, які мають враховуватись в туристичному бізнесі 3 метою забезпечення безпеки туристичної діяльності. Світове співтовариство дедалі більше уваги приділяе забезпеченню достатніх фінансових ресурсів для проведення превентивних заходів із запобігання ризиків у сфері туризму. Особливої актуальності це питання набуває в умовах глобалізації, яка всебічно впливає на світову та національну безпеку. Туризм, як жодна інша галузь, підвладний впливу «форс-мажорів» - війн, природних катаклізмів, епідемій тощо.

Майже всі країни входять в міжнародний туристичний ринок, але розподіл туристичних потоків проходить 
нерівномірно в зв 'язку з різним рівнем соціально-економічного розвитку країн, наявності жорсткої конкуренції $i$, як наслідок цього, різним рівнем безпеки туризму.

Враховуючи те, що ключовою фігурою в системі безпеки туризму повинен виступати саме турист (людина), безпека туризму є важливим завданням не лише для суб'єктів туристичного сектору окремо взятої країни. Над питаннями безпеки туризму працюють відповідні міжнародні організації: Міжнародна організація праці, Всесвітня організація охорони здоров'я, Організація Об'єднаних Націй, Міжнародна організація цивільної авіації, Міжнародна морська організація, Всесвітня організація охорони здоров'я та інші.

Аналіз останніх досліджень $i$ публікацій та виділення невирішених частин загальної проблеми. Останнім часом активізувалися наукові дослідження щодо проблем розвитку туризму в Україні. Особливу увагу вітчизняні науковці приділяють напрямкам розвитку туристичної галузі, розрахунку вартості туристичного продукту та прогнозуванню туристичних потоків.

Питанням безпеки туризму присвячено чимало публікацій. Методичні та практичні аспекти безпеки туризму розглядаються у працях таких вчених, як Н. Галла, О. Заноско, Н. Корж, І. Маркіна [2-4] та інші. Слід зауважити, що більшість вітчизняних авторів зосереджують свою увагу на економічній безпеці держави чи туристичних підприємств, а теоретичним аспектам безпеки туризму приділяється недостатньо уваги. Більшість вітчизняних вчених, що працюють у різних галузях науки, у своїх працях не наводять чіткого визначення безпеки туризму. В той же час у зарубіжній науці $\epsilon$ достатньо досить грунтовних теоретичних узагальнень щодо змісту та структури категорії «безпека туризму». Так, у цьому контексті варто згадати праці таких вчених, як К. Зімані, I.
Коварі [5], Й. Мансфелд, А. Пізам [6], С. Мічурін [7] та ін. В той же час, незважаючи на наявність певних напрацювань у зарубіжній та вітчизняній науці, наразі не сформовані чіткі підходи до трактування безпеки туризму, ii класифікації.

Окреслені напрямки наукових пошуків, на наш погляд, є актуальними i потребують особливої уваги 3 боку науковців, що і зумовило вибір теми та визначення мети і завдань дослідження.

Метою cmammi $\boldsymbol{\epsilon}$ розробка теоретико-методологічних основ формування системи безпеки туризму як основної умови підвищення конкурентоспроможності туристичної галузі України.

Виклад основного матеріалу. Саме поняття безпека визначається як стан захищеності життєво важливих інтересів особистості, суспільства і держави від внутрішніх і зовнішніх загроз. Під життєво важливими інтересами розуміється сукупність потреб, задоволення яких, надійно забезпечує існування i можливості прогресивного розвитку особистості, суспільства, держави [8]. Безпека в галузі туризму це сукупність факторів, що характеризують соціальний, економічний, правовий та інший стан забезпечення прав і законних інтересів громадян, юридичних осіб та держави в галузі туризму.

На думку багатьох науковців, трактування безпеки туризму за останні десятиліття зазнало суттєвих змін. За масштабом слід виділяти глобальну, макрорегіональну, національну, регіональну та локальну безпеку туризму.

Цілком зрозуміло, що на сучасному етапі стан розвитку туризму безпосередньо залежить від забезпечення безпеки туристів, від рівня захисту їх життя, здоров'я, майна. Висловлюючись про безпеку туризму, слід підкреслити, що це широке, складне i багатогранне поняття. Не можна спрощувати заходи безпеки туризму i представляти їх 
примітивно, як охорону туристських об'єктів або цілодобових «сек'юріті» у готелях. Очевидно, що гарантування безпеки має базуватися на системному підході, оскільки сама категорія «безпеки туризму» $\epsilon$ надзвичайно складною та багатоаспектною. На наш погляд, безпека туризму є універсальною категорією, що має економічний, соціальний, екологічний та інший зміст, поєднує в собі забезпечення інтересів як виробників, так i споживачів туристичних послуг, а також об'єктів, на які спрямована туристична діяльність. Виходячи 3 цього доцільно диференціювати безпеку туризму на економічну, соціальну та екологічну, а у структурі безпеки туризму виділяти політичну безпеку, соціальну безпеку, безпеку здоров'я та життя туристів, безпеку персональних даних, правову безпеку туристів, споживчу безпеку, безпеку комунікації, екологічну безпеку, безпеку обслуговування та інше.

На даний час, заходи 3 підвищення безпеки в туризмі в нашій країні мають рухатися в двох напрямках: по-перше, забезпечення комплексних питань безпеки, a по-друге, забезпечення безпосередньо безпеки туристів.

В той же час, слід зауважити, що досі не розроблено вичерпної класифікації безпеки туризму за багатьма ключовими ознаками.

На нашу думку, класифікувати безпеку туризму за змістом доцільно як:

- геополітична, політична та військово-політична безпека туризму;

- політико-правова безпека;

- релігійна, культурна;

- кримінальна, безпека надзвичайних ситуаціях (в тому числі при скоєнні терактів);

- безпека

життєдіяльності

(медична, безпека харчування, безпека послуг проживання, послуг обслуговування);

- фінансова (валютна);

- екологічна, реакреаційна;
- безпека

пересування

(транспортна);

- інженерна, технологічна

(безпека споруд та обладнання);

- інформаційна.

Автори не претендують на повноту наведеного списку i вважають його відкритим до аргументованого доповнення .

Думки вчених щодо структури та ключових функцій безпеки туризму як складної, відкритої та динамічної системи суттєво різняться.

Сама безпека туризму має системоформуючий характер у туристичній діяльності, адже може розглядатися як головна споживча властивість, якою об'єктивно і реально повинна володіти туристична послуга, у той час як інші споживчі іiі властивості можуть реалізуватися повною мірою тільки у випадку, якщо безпека туризму буде гарантована.

У рамках такого трактування категорії безпеки туризму системоформуючу роль відіграє поняття загрози, яка розглядається як деструктивне явище (подія), що може зумовити посилення регресивних тенденції розвитку туристичної діяльності на усіх ієрархічних рівнях i для усіх суб'єктів.

Безпека туризму повинна бути заснована на ретельно продуманій, цілеспрямованій i комплексній системі заходів з метою створення таких умов, при яких будь-яка подія з туристом свідомо не могло б відбутися [7].

Експерти Всесвітньої туристської організації пропонують такі шляхи розв'язання проблеми:

- розробка та впровадження в життя норм безпеки подорожей та місць перебування туристів;

- інформування й просвітницька робота громадськості;

- створення інституційних рамок для розв'язання проблем, пов'язаних 3 безпекою туристів, зокрема в 
екстремальних ситуаціях; міжнародне співробітництво на різних рівнях.

При наданні туристських послуг повинен бути забезпечений прийнятний рівень ризику для життя i здоров'я туристів, як у звичайних умовах, так і в надзвичайних ситуаціях (стихійних

лих,пожежі та т. п.), що виникають в країні подорожей.

Безпеку

туризму

можна підрозділити на ряд рівнів, починаючи 3 безпеки засобів і транспорту, готельних i рекреаційних комплексів, туристичних центрів, а також країни в цілому. При цьому заходи безпеки не повинні завдавати шкоду інтересам, обмежувати права i свободи як самих туристів, так $\mathrm{i}$ місцевих жителів.

Прикладом такої діяльності може слугувати мексиканська програма безпеки туризму. У квітні 1996 р. під керівництвом Міністерства туризму Мексики і Ради 3 розвитку туризму мерії в м. Мехіко була проведена конференція 3 вироблення державної програми безпеки туризму. Мексиканська влада надали саме серйозне значення даної проблеми, розглядаючи іiі як найважливіший елемент загальної національної програми розвитку туризму в країні.

Програма безпеки туризму включає наступні заходи:

- створення інформаційних пункті

в у місцях в"їзду іноземних туристів в аеропортах, морських терміналах та інших прикордонних пунктах для надання їм консультаційної та іншої допомоги. Частина цієї роботи покладається на посольства Мексики в країнах світу, звідки йде основний потік туристів, що прибувають;

- видання під егідою міністерства туризму

інформаційних матеріалів по Мексиці, соціально-культурним і національним особливостям іiі населення. У цих публікаціях зафіксовано місця підвищеної криміногенної обстановки в ряді туристських центрів, дані огляду практики дій місцевих злочинних елементів по відношенню до іноземців;

- прийняття законодавчих та інших нормативних актів щодо посилення заходів покарання за шахрайство щодо туристів водіями таксі, службовцями готелів, ресторанів, магазинів i інших установ обслуговування;

- створення «туристської поліції» - єдиного центру інформації та мобільного поліцейської служби м. Мехіко з надання термінової допомоги туристам. При в'їзді в країну кожному туристу вручаються координати і телефони цього центру (персонал центру вільно володіє шістьма іноземними мовами (англійською, французькою, німецькою, італійською, шведською та японською)).

До основних заходів також віднесена необхідність підвищення вимог щодо надійності та безпеки автотранспорту, який використовувається місцевими турфірмами, а також збереження майна туристів у готелях.

Окремий план безпеки складений 3 міжнародного аеропорту

М. Мехіко як найбільшому елементу інфраструктури туризму, що обслуговує більше 20 млн пасажирів на рік.

Створення подібних програм забезпечення безпеки туризму $\epsilon$ позитивним та цікавим прикладом для багатьох країн.

Аналогічне завдання стоїть і перед вітчизняними органами управління туризмом, але окрім законодавчо закріплених окремих норм на практиці ситуація виглядає зовсім іншим чином.

Вимоги до безпеки обслуговування для конкретних видів туристських послуг встановлюються нормативною документацією на відповідні види послуг: державними стандартами, правилами, статутами, кодексами та іншими.

Так, закон України «Про туризм» у розділі VIII надає гарантії безпечного перебування туристів на території України i зобов'язує органи влади та суб'єктів 
туристичної діяльності розробити комплекс заходів 3 безпеки туристів. Зокрема, в статті 26 сказано: «Місцеві органи державної виконавчої влади в галузі туризму розробляють i організовують виконання регіональних програм забезпечення захисту та безпеки туристів, особливо в місцях туристичної активності. Суб'єкти туристичної діяльності розробляють конкретні заходи щодо забезпечення безпеки туристів, екскурсантів, які беруть участь у туристичних подорожах, походах, змаганнях, запобігання травматизму та нещасним випадкам i несуть відповідальність за їх виконання» [9].

Органи державної влади та органи місцевого самоврядування, їх посадові особи в межах своїх повноважень повинні вживати заходи, спрямовані на забезпечення закріплених Конституцією України прав громадян на безпечне для життя і здоров'я довкілля при здійсненні туристичних подорожей, захист громадян України за їі межами [1].

В Україні діє міждержавний стандарт (ГОСТ 28681.1-95) «Туристичноекскурсійне обслуговування», який передбачає порядок проектування туристичних послуг, включаючи розгляд можливих ризиків, які можуть викликати негативні наслідки і спричинити шкоду здоров'ю туриста та його майну [10].

За чинним законодавством України суб'єкти туристичної діяльності 3 метою забезпечення безпеки туристів зобов'язані: інформувати туристів про можливі небезпеки під час подорожі, про виконання загальнообов'язкових вимог та запобіжних чи попереджувальних заходів (медичних щеплень тощо); створювати безпечні умови в місцях надання туристичних послуг, забезпечувати належне облаштування трас походів, прогулянок, екскурсій тощо; виконувати спеціальні вимоги 3 безпеки під час надання туристичних послуг 3 підвищеним ризиком тощо. Особи, які організовують експлуатацію туристичних ресурсів, зобов'язані забезпечувати виконання вимог з охорони довкілля та культурної спадщини, а також вживати заходів 3 мінімізації або припинення шкідливого впливу на довкілля i соціально-культурне середовище та компенсувати завдані при цьому збитки. Держава забезпечує захист законних прав та інтересів іноземних туристів відповідно до законодавства та міжнародних договорів України й гарантує захист законних прав та інтересів громадян України, які подорожують за кордон [1].

Розглядаючи питання безпеки туризму, не слід забувати про заходи дотримання звичайних правил поведінки, що виключають потрапляння туриста в надзвичайні ситуації. Мова йде про елементарну обережність.

$$
\text { Одним }
$$

головних психологічних аспектів

забезпечення безпеки в туризмі, без яких неможлива робота системи безпеки вважається повага звичаїв, звичок і антипатій місцевих жителів, а також знання англійської або місцевої мови.

Аналіз показав, що турист порушує вимоги безпеки з наступних причин:

- через незнання цих вимог;

- по небажанню виконувати відомі йому вимоги безпеки;

- у зв'язку з невмінням виконувати вимоги;

- у зв'язку 3 неможливістю виконати вимоги (з причин, не залежних від туриста).

Висновки. Безпека туристів, їх благополуччя в місцях туристського призначення не можна розглядати у відриві від інших суспільних чи національних інтересів приймаючої країни i навколишнього середовища в цілому. При розробці і проведенні в життя норм безпеки для сфери туризму та захисту туристів інтереси тих, хто відвідує i приймає, повинні бути взаємно гармонізовані. Забезпечення якості послуг та безпеки в туризмі відбувається на 
різних рівнях, що включають у себе: туристські підприємства; адміністрація туристських центрів; місцеві влади; національні органи по туризму та центральні власті держав; міжнародні організації та міждержавні органи. Кожен 3 цих рівнів має вносити свій внесок у туризм.

У нашій країні безпеку i якість туристичних послуг тільки прагнуть довести до світових стандартів, незважаючи на те, що в сфері туризму діє значна кількість нормативно-правових актів. За останні роки були внесені зміни, які раніше діяли в законодавстві даної сфери. Але, враховуючи складнощі, які було розглянуто, їх постійну динаміку, варто зробити висновки про необхідність подальшого вдосконалення правового регулювання в області туризму і його безпеки.

Саме скоординована спільна робота 3 організації безпеки туризму на рівнях: держава - регіональні органи влади i управління туристичний сектор(туроператори та турагенції) турист, зможе сприяти організації заходів безпеки на системному, дієвому рівні.

\section{СПИСОК ЛІТЕРАТУРИ}

1. Закон України «Про туризм» [Електронний ресурс]. - Режим доступу: http://zakon0.rada.gov.ua/laws/show/324/95$\% \mathrm{D} 0 \% \mathrm{~B} 2 \% \mathrm{D} 1 \% 80$

2. Галла Н.M. Основні напрямки та принципи забезпечення економічної безпеки туристичного підприємства / Н.М. Галла // Індустрія гостинності в країнах Європи : тези III міжнар. наук.-практ. конференції (м. Сімферополь, 4-6 грудня 2009 р.). - Сімферополь: ВіТроПринт, 2009. - C. 10-13.

3. Корж Н.В. Формування системи економічної безпеки індустрії туризму як складової стійкого розвитку туризму в Україні [Електронний ресурс] / Н.В. Корж, О.В. Заноско // Економіка. Управління. Інновації. Електронне наукове фахове видання. - 2011. - № 2. Режим доступу : http://www.nbuv.gov.ua/ejournals/eui/2011_2/11knvtvy.pdf

4. Маркіна I.A. Управління безпекою туристичного бізнесу / I.A. Маркіна // Экономика Крыма. - 2012. - № 1 (38). - C. 174-176.

5. Kovari I. Safety and Security in the Age of Global Tourism // I. Kovari, K. Zimanyi // Applied Studies in Agribusiness and Commerce. - Budapest, 2011. - №3-4. Vol. 5. -P. 59-61.

6. Mansfeld Y. Tourism, Security and Safety: from theory to practice / Y. Mans // Y. Mansfeld, A. Pizam. - Oxford: Elsevier Butterworth-Heinemann, 2006. - 2006 - 376 p.

7. Мичурин С.Б. Безопасность в туризме : методологический и пространственный аспекты : автореф. дисс. ... канд. геогр. наук / С.Б. Мичурин; Перм. гос. нац. исслед. ун-т. - Пермь, 2012. -22 c.

8. Смолій B.А. Енциклопедичний словник-довідник 3 туризму / В.А. Смолій, В.І. Цибух ; за ред. В.К. Федорченко. - К. : ВД "Слово", 2006. -372 c.

9. Закон України «Про внесення змін до Закону України «Про туризм» від 18 листопада 2003 p. № 1282-IV. [Електронний ресурс]. - Режим доступу: http://zakon0.rada.gov.ua/

10. ГОСТ

28681.3-95

Межгосударственный стандарт. Туристско-экскурсионное обслуживание. Требования по обеспечению безопасности туристов и экскурсантов. Дата введения в Украине 1997. 01. 01 // Уніфіковані технології готельних послуг: навч. посіб. / За ред. проф. В. К. Федорченка, Л. Г. Лук'янова, Т. Т. Дорошенко, І.М. Мініч. — К.: Вища школа, 2001. — 237 с.

Стаття надійшла: 15.09.16p. 